\title{
PROGRAM KESADARAN BAHAYA MERKURI DAN SIANIDA DI DAERAH LINGKAR TAMBANG: STUDI KASUS DAERAH KAO TELUK, MALIFUT DAN KAO, HALMAHERA UTARA
}

\author{
B. Sulistijo ${ }^{(1)}$, Chusharini Chamid ${ }^{(2)}$, Electronita Duan ${ }^{(3)}$, Johana Tandisalla $^{(3)}$, Razak \\ Karim $^{(4)}$, Ruslan Umar ${ }^{(4)}$, Nurany ${ }^{(5)}$, Suyeti Amir ${ }^{(6)}$, Steven Ewamony ${ }^{(6)}$ \\ ${ }^{1}$ Kelompok Keahlian Eksplorasi Sumberdaya Bumi Institut Teknologi Bandung, Jl. Ganesa No.10 Bandung, \\ Indonesia. e-mail: budis@ mining.itb.ac.id \\ ${ }^{2}$ Prodi Teknik Pertambangan Universitas Islam Bandung, Jl. Tamansari No. 1 Bandung, Indonesia. \\ ${ }^{3}$ Politeknik Perdamaian Halmahera, Jl. Raya Tobelo, Tobelo \\ ${ }^{4}$ Universitas Muhammadiyah Maluku Utara, Jl. KH Ahmad Dahlan No 100, Ternate, \\ ${ }^{5}$ Fakultas Teknik Universitas Negeri Khairun, Jl. Pertamina kampus II Ternate \\ ${ }^{6}$ Dinas Lingkungan Hidup, Kabupaten Halmahera Utara, Jl.Kawasan Pemerintahan, Tobelo
}

\begin{abstract}
ABSTRAK
Daerah lingkar tambang adalah daerah yang sangat rentan untuk tumbuhnya pengolahan emas dengan menggunakan metode amalgamasi dan sianidasi yang diinisiasi oleh masyarakat pendatang. Oleh fungsi waktu akhirnya masyarakat lokal menguasai teknologi amalgamasi dan sianidasi. Aktifitas ini semakin marak jika bijih emas mempunyai sifat yang cocok untuk diolah dengan amalgamasi dan dilanjutkan dengan sistem sinaidasi.

Tambang rakyat ini merupakan isu yang kompleks, dan sama halnya dengan yang terjadi di berbagai negara lain, umumnya orang-orang yang terlibat dalam kegiatan tambang jenis ini di Kao teluk, Malifut dan Kao kabupaten Halmahera Utara merupakan orang-orang yang memiliki tingkat pendidikan yang rendah dan tidak memiliki alternatif mata pencaharian yang lain yang lebih baik. Menjadi tanggungjawab bagi setiap individu dalam masyarakat untuk memberikan pengetahuan pada orang-orang yang terlibat dalam kegiatan tambang rakyat dan tambang skala kecil ini dalam praktik penggunaan merkuri dan sianida dengan aman.

Metode ini telah berhasil dengan baik dengan melibatkan lebih dari 900 orang mulai dari anak-anak SD, SMP dan SMA yang orangtuanya/keluarganya terlibat dalam pengolahan emas, Puskemas, Remaja Gereja, Jemaat Gereja, Ibu-ibu Pengajian, Puskemas, Ibu-ibu di enclove pengolahan emas serta penambangan emas itu sendiri.

Terbentuknya penyuluh-penyuluh untuk pertambangan emas traditional yang mengerti adat dan bahasa lokal sangat penting dan lebih efektif jika didukung bahan-bahan penyuluhan yang kominikatif yang mengacu kepada adat dan kegiatan local.
\end{abstract}

Kata kunci: Merkuri, Sianida, Tambang Rakyat, Kesadaran Bahaya Tambang. 


\section{Pendahuluan}

Daerah lingkar tambang adalah daerah yang sangat rentan untuk tumbuhnya pengolahan emas dengan menggunakan metode amalgamasi dan sianidasi yang diinisiasi oleh masyarakat pendatang. Oleh fungsi waktu akhirnya masyarakat lokal menguasai teknologi amalgamasi dan sianidasi. Aktifitas ini semakin marak jika bijih emas mempunyai sifat yang cocok untuk diolah dengan amalgamasi dan dilanjutkan dengan sistem sianidasi. Sayangnya teknologi sederhana dalam pengolahan emas mengabaikan aspek-aspek keselamatan kerja baik bagi dirinya, keluarga maupun masyarakat sekitar lokasi pengolahan. Kondisi ini diperburuk dengan adanya pengambilan bijih oleh penambangan tanpa ijin di daerah yang sudah berijin sehingga bijih yang diolah semakin besar karena kondisi sarana dan prasarana yang lebih baik.

Kondisi ini terjadi juga di daerah lingkar tambang PT Nusa Halmahera Minerals. Sejak penuangan emas pertama kali di Gosowong pada tahun Juli 1999 (www.nhm.co.id) usaha penambangan emas tanpa ijin di lokasi CoW (Kontrak karya) PT Nusa Halmahera Minerals tumbuh dengan intensitas meningkat tajam pada tahun 2002 dan 2003 dimana kegiatan penambangan menjadi berita nasional (d'Hondt,2011).

Para pelaku tambang di dalam lingkar tambang melakukan kegiatan penambangan tanpa perlindungan apapun dan mereka memproses amalgam dan sianida di lingkungan mereka sendiri menggunakan obor las (blowtorch) yang ditujukan langsung untuk mengolah amalgam atau karbon aktif. Kondisi ini dapat menimbulkan resiko pencemaran udara, tanah dan air. Jika kegiatan ini tidak terkontrol maka di kemudian hari dapat memunculkan tuduhan seolah-olah pencemaran air, tanah dan udara disebabkan oleh aktifitas penambangan berijin. Meskipun tidak menutup kemungkinan perusahaan tambang berijin melakukan pencemaran.

Meskipun usaha tambang rakyat di sekitar Kao Teluk, Kao dan Malifut baru ada setelah kegiatan PT Nusa Halmahera Minerals berjalan, tetapi tambang rakyat dikenal sebagai bagian penting sistem perkembangan perdesaan oleh beberapa negara dan agen-agen pengembangan seperti Bank Dunia (Chusharini et.al, 2003). Tambang rakyat menyediakan uang tunai yang sangat cair bagi perekonomian pedesaan sehingga membantu perkembangan pertanian, memperkuat struktur ekonomi dan membantu mengurangi kemiskinan di pedesaan (Sulistijo, et.al, 1996). Masalah lingkungan menjadi masalah yang luar biasa besar jika baik masyarakat sekitar lingkar tambang maupun penambang tidak mengetahui bahaya dari merkuri dan sianida bagi lingkungan.

Program kesadaran bahaya merkuri dan sianida melibatkan semua pihak yang berkepentingan selain dari pekerja tambang itu sendiri juga keluarga melalui sekolah formal mulai dari Sekolah Dasar sampai Sekolah Lanjutan Atas; Sekolah Informal seperti Sekolah Minggu; melalui pengajian ibu-ibu dan Jemaat Gereja. Melalui tenaga medik seperti PUSKEMAS dan sekolah kejuruan (sekolah 
keperawatan dan sekolah Geologi dan Pertambangan).

Untuk mengetahui capaian hasil dilakukan test secara sederhana sebelum dan sesudah pemberian pelatihan kesadaran bahaya merkuri dan sianida.

\section{Komunitas Sekitar Lingkar Tambang}

Kabupaten Halamahera Utara mempunyai luas sekitar $3.896,09 \mathrm{~km}^{2}$ atau $12,18 \%$ dari propvinsi Maluku Utara. Daerah ini terdiri dari 17 Kecamatan, 196 Desa dengan jumlah penduduk 183.596 jiwa. Masyarakat lokal terdiri dari pemilik lahan tradisional dan transmigran. Transmigran ini baik dari program pemerintah maupun transmigran mandiri dari seluruh wilayah Indonesia dan transmigran lokal dari Maluku dan sekitarnya (Bugis, Banjar dan Jawa). Pemilik lahan traditional dan transmigran awalnya bekerja sebagai petani sebelum ada PT Nusa Halmahera Minerals. Mereka pada umumnya sebagai petani kelapa sehingga mempunyai waktu luang yang cukup untuk melakukan kegiatan lain selain petani kelapa.

Ada beberapa desa sekitar lingkar tambang yang berdekatan dengan PT Nusa Halmahera Minerals,yaitu: Tabanoma, Dumdum, Beringin, Tabobo, Bukit Tinggi dll (Peta 1). Hampir semua masyarakat Kampung Beringin adalah penambang dan bukan penduduk asli dari daerah ini. Saat ini mereka melakukan penambangan di daerah Anggrek dan Dumping area. Aktivitas penambangan di Anggrek saat ini lebih di dominasi oleh pengambilan bijih di daerah "kadar rendah" dengan menggunakan "monitor". Aktivitas ini akan menyebabkan kekeruruhan di daerah hilir dari sungai Tabobo.

Komunitas penambang rakyat terbesar ada di Desa Beringin. Pada masa masa keemasan, aktivitas di desa ini di dominasi oleh pengolahan emas dengan menggunakan trommel (gelundung) dengan cara amalgamasi. Tailing dari trommels di kumpulkan pada kolam penampungan. Pada saat tertentu tailing di kolam penampungan dikuras untuk di proses dengan metode sianidasi di daerah Kobok dan Tabanoma. "The sicken mercury" dari tailing diambil dengan menggunakan sentrifugal sebelum dikirim ke tangki sianidasi.

Pada saat ini aktfitas pengolahan dengan menggunakan amalgamasi dan sianidasi berkurang akibat menurunnya kiriman bijih dengan kadar ekonomis dan sebagian dari mereka beralih menjadi pemungut besi tua.

Dari hasil wawancara banyak dari anggota keluarga yang ikut dalam program penyadaran pemakaian merkuri dan sianida terlibat dalam kegiatan tambang rakyat mulai dari penambangan sampai pengolahan 


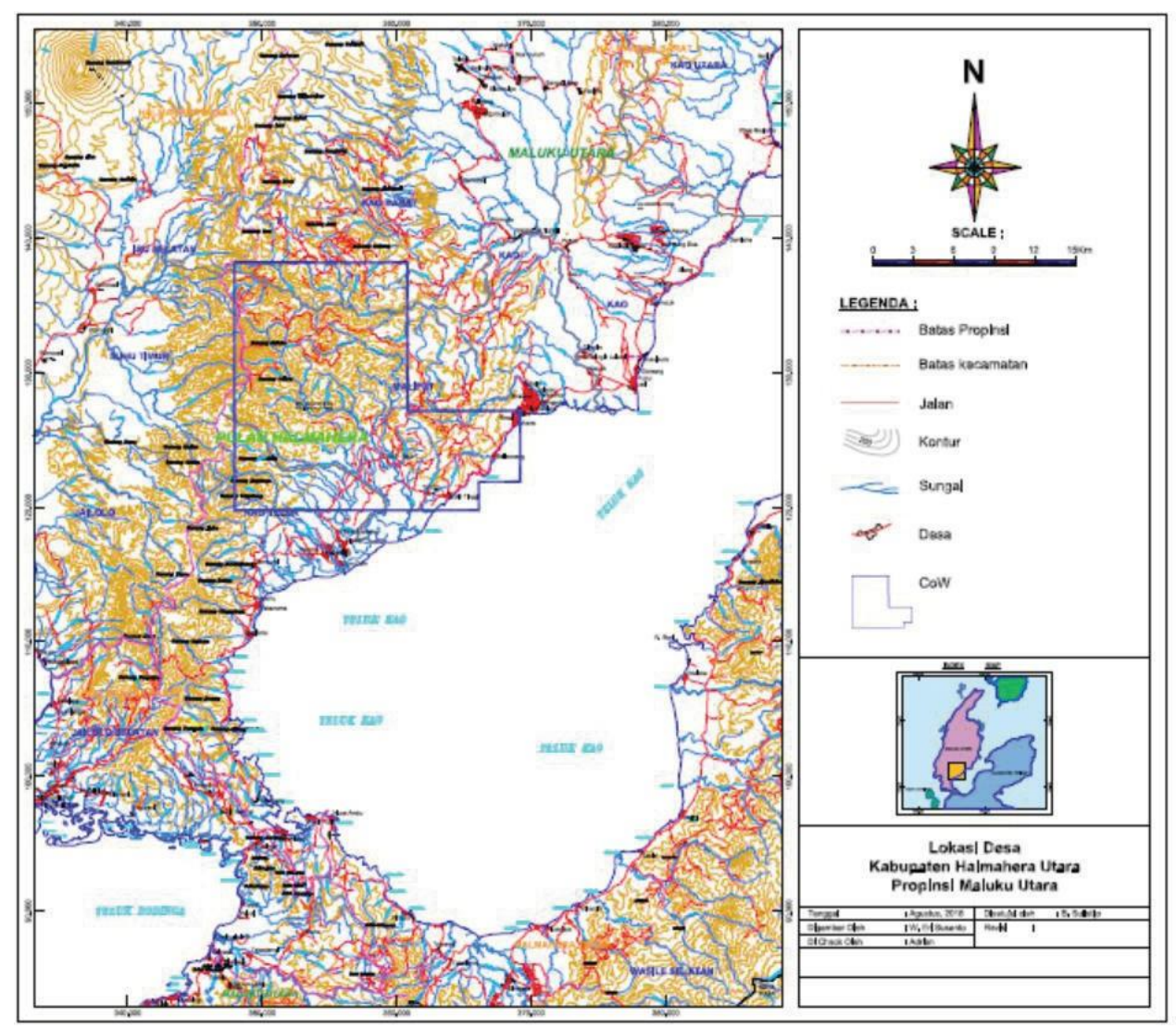

Peta.1: Lokasi Desa di sekitar Lingkar Tambang

\section{Pendekatan}

Program kesadaran pemakaian merkuri dan sianida dilakukan di Kecamatan Kao Teluk, Malifut dan Kao. Total 929 orang terlibat dalam sosialisasi. Saat ini aktifitas penambangan dan pengolahan terkonsentrasi di Kecamatan Malifut. Pada saat periode keemasan beberapa tahun yang lalu banyak pengolahan emas yang aktif di daerah Kecamatan Kao Teluk. Pada saat ini hanya ada satu unit pengolahan emas dengan sianidasi yang beroperasi secara tidak rutin di daerah Kecamatan Kao Teluk.

Untuk mengetahui tingkat pengetahuan sebelum sosialisasi dan sesudah sosialisasi diakukan test sederhana yang digunakan sebabagi base line study.

Tabel 1. Komponen Utama Baseline Study

\begin{tabular}{|l|l|l|}
\hline \multicolumn{1}{|c|}{ Pengetahuan Merkuri-sianida } & \multicolumn{1}{|c|}{ Profil peserta } & Kondisi Lingkungan \\
\hline Pengetahuan Merkuri & Jenis kelamin dan umur & Polusi sungai \\
\hline $\begin{array}{l}\text { Bagaimana Merkuri dan sianida } \\
\text { masuk ke tubuh }\end{array}$ & Pendidikan formal dan non formal & \\
\hline
\end{tabular}




\begin{tabular}{|l|l|l|}
\hline \multicolumn{1}{|c|}{ Pengetahuan Merkuri-sianida } & \multicolumn{1}{|c|}{ Profil peserta } & Kondisi Lingkungan \\
\hline Kegunaan merkuri dalam sehari-hari & Lokasi & \\
\hline $\begin{array}{l}\text { Sumber polusi merkuri ke } \\
\text { lingkungan }\end{array}$ & & \\
\hline $\begin{array}{l}\text { Bahaya merkuri -sianida ke } \\
\text { kesehatan manusia }\end{array}$ & & \\
\hline Proses masuknya merkuri ke janin & & \\
\hline $\begin{array}{l}\text { Manfaat sianida untuk kehidupan } \\
\text { sehari-hari }\end{array}$ & & \\
\hline Apa itu sianida? & & \\
\hline $\begin{array}{l}\text { Bagaimana menyimpan merkuri dan } \\
\text { sianida yang aman }\end{array}$ & & \\
\hline $\begin{array}{l}\text { Prosedure setelah kontak dengan } \\
\text { merkuri dan sianida. }\end{array}$ & & \\
\hline
\end{tabular}

\section{Hasil}

\subsection{Identitas Responden}

\subsubsection{Umur dan tempat tinggal}

Ada 771 orang yang aktif dalam kegiatan ini. Peserta didominasi oleh perempuan (57\%) (Gambar 1). Umur responden yang berumur 13-18 tahun sebanyak $49 \%, 19-30$ tahun $4 \%$ dan diatas 30 tahun sebanyak $10 \%$ dan kurang dari 12 tahun sebanyak $38 \%$ (Gambar 2). Dapat dilihat bahwa hampir semua yang terlibat dalam sosialisasi ini berumur masa masa sekolah. Karena pada saat ini kegiatan tambang rakyat hampir semua berada di Kecamatan Malifut maka hal ini mencerminkan hampir $60 \%$ dari peserta berasal Kecamatan Malifut, 33\% dari Kecamatan Kao Teluk dan 7 \% dari Kecamatan Kao (Gambar 3).

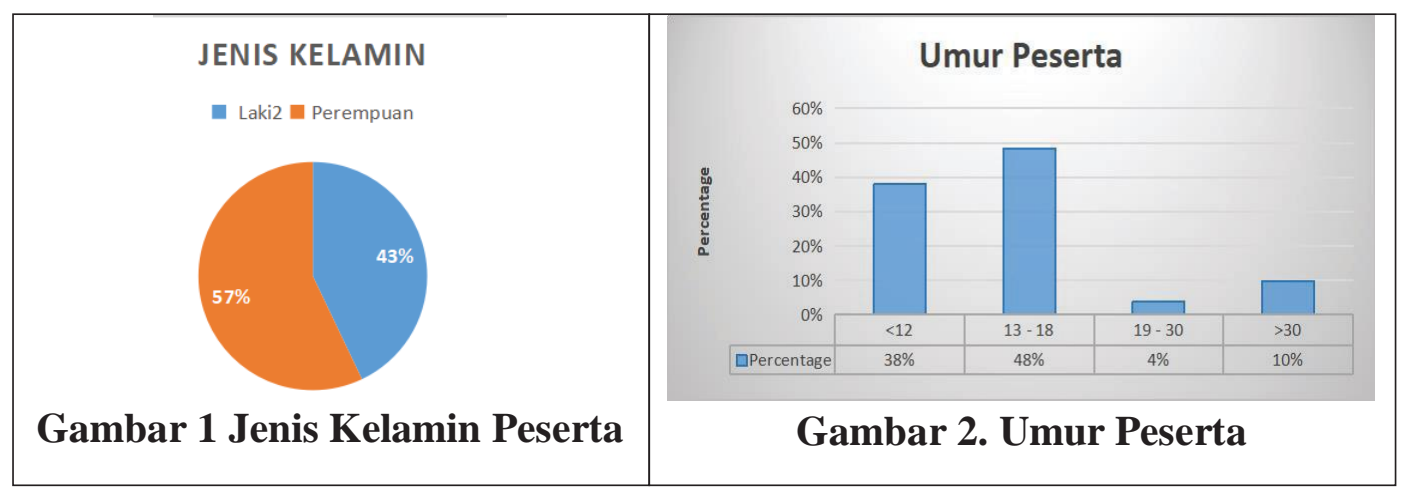




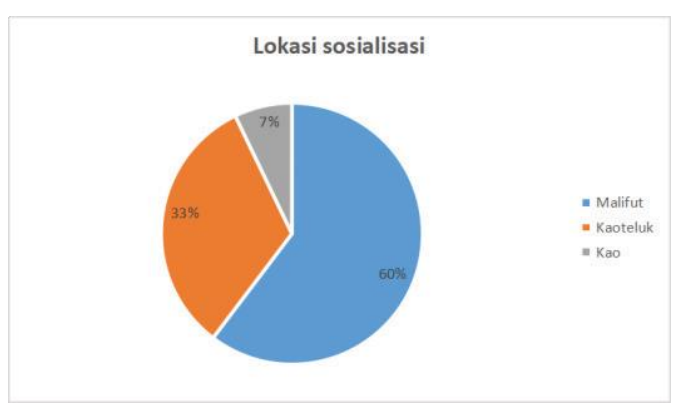

Gambar 3. Lokasi Sosialisasi

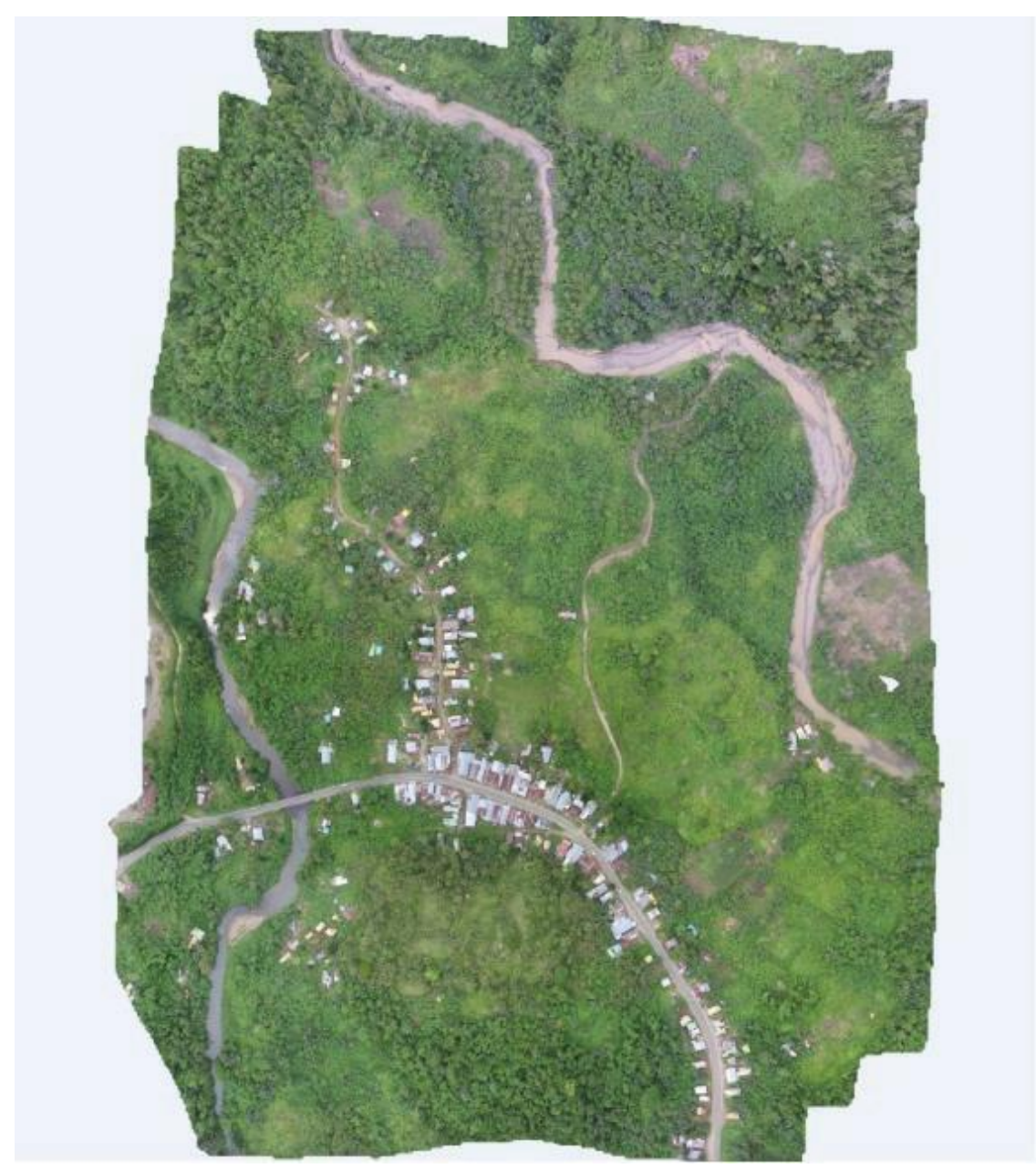

Photo 1 Tipikal Daerah Studi

\subsubsection{Latar belakang Peserta}

Latar belakang peserta $31 \%$ memepunyai pendidikan Sekolah Lanjutan Tingkat Atas, $15 \%$ mempunyai pendidikan Sekolah Lanjutan Tingkat Pertama, 33 $\%$ adalah anak-anak Sekolah Dasar, Komunitas Keagamaan $15 \%$ dan Komunitas Penambang $6 \%$ (Gambar 4). Komunitas penambang sangat kecil karena pada saat ini kegiatan sedang pada titik yang terendah.

Sosialisasi ke anak-anak sekolahan dan Komunitas Keagamaan agar dapat mempercepat pesan bahaya merkuri dan sianida diantara keluarga dan komunitas. 
Banyak dari anak-anak yang terlibat dalam sosialisasi mempunyai keluarga yang terlibat dalam kegiatan tambang rakyat.

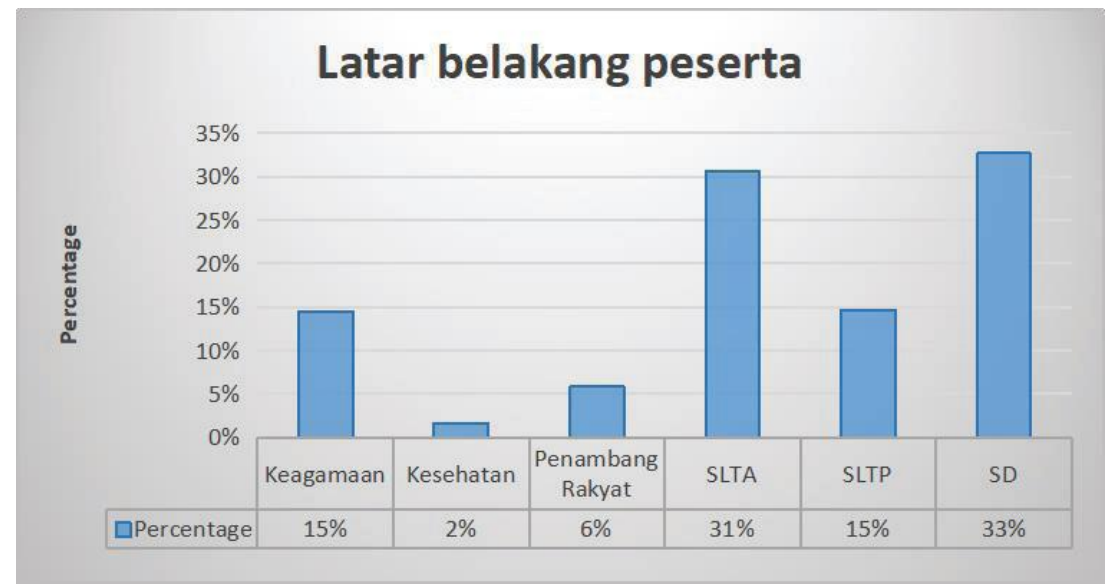

Gambar 4. Latar Belakang Peserta

\section{Kegiatan Program Penyadaran Pemakaian Merkuri dan Sianida}

Tambang rakyat ini merupakan isu yang kompleks, dan sama halnya dengan yang terjadi di berbagai negara lain, umumnya orang-orang yang terlibat dalam kegiatan tambang berada di Kao Teluk, Malifut dan Kao Kabupaten Halmahera Utara merupakan orang-orang yang memiliki tingkat pendidikan yang rendah dan tidak memiliki alternatif mata pencaharian yang lain yang lebih baik. Menjadi tanggungjawab bagi setiap individu dalam masyarakat untuk memberikan pengetahuan pada orang-orang yang terlibat dalam kegiatan tambang rakyat dan tambang skala kecil ini dalam praktik penggunaan merkuri dan sianida dengan aman. Untuk itu program ini melibatkan: Universitas Muhamadiyah Maluku Utara, Universitas Negeri Khairun, Politeknik Padamara, ESDM Propinsi Maluku Utara dan Dinas Lingkungan Hidup Kabupaten Halmahera Utara

Pendekatan yang dilakukan sebagai solusi dari permasalahan melalui ini dilakukan melalui beberapa program berikut:

\section{a. Kampanye}

Pendistribusian poster-poster ke sekolah-sekolah, Posyandu, atau Puskesmas. Poster-poster tersebut akan didesain dengan warna-warna yang menarik, penggunaan kata-kata atau kalimat yang sederhana, pendek, dan jelas, namun dapat dimengerti dengan menggunaan bahasa Indonesia dan bahasa lokal ("Bahasa Indonesia Pasar") 


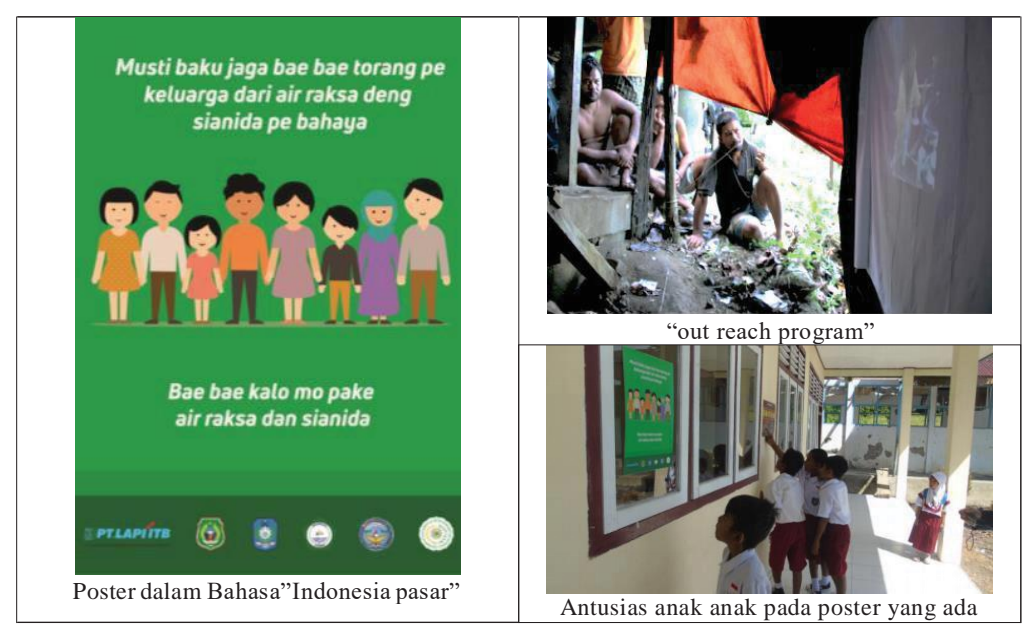

Gambar 5. Contoh Kegiatan di Lapangan

\section{b. Lokakarya (workshop) atau pelatihan (training) untuk anak-anak}

Lokakarya (workshop) atau pelatihan (training) untuk anak-anak ini akan menjadi lebih efektif jika lokakarya (workshop) atau pelatihan (training) menggunakan material audio-visual dibandingkan dengan penggunaan metode konvensional (metode pengajaran guru-murid). Dengan menggunakan film animasi, kita mencoba untuk mempresentasikan sesuatu bahasan yang berat atau serius dan berbahaya dalam bentuk yang informatif melalui teknik-teknik yang universal dan menyenangkan tanpa menghilangkan tujuan utama.

\section{c. Lokakarya (workshop) atau pelatihan (training) untuk orang dewasa dilokasi Penambangan Rakyat, Gereja, Sekolah, Pengajian, Puskesmas.}

Seperti disebutkan sebelumnya mengenai efektifitas penggunaan film sebagai material presentasi untuk menggambarkan dampak merkuri dan sianida bagi kehidupan manusia dan cara yang benar dalam penanganan merkuri dan sianida

d. Demonstrasi sistem retort untuk pelaku tambang rakyat di lokasi penambangan rakyat

\section{Kesimpulan}

Metode ini telah berhasil dengan baik dengan melibatkan lebih dari 900 orang mulai dari anak-anak SD, SMP dan SMA yang orangtuanya/keluarganya terlibat dalam pengolahan emas, Puskemas, Remaja Gereja, Jemaat Gereja, Ibu-ibu Pengajian, Puskemas, Ibu-ibu di enclove pengolahan emas serta penambangan emas itu sendiri.

Terbentuknya penyuluh-penyuluh untuk pertambangan emas traditional yang mengerti adat dan bahasa local lebih efektif karena didukung bahan-bahan penyuluhan yang kominikatif. 


\section{Pustaka}

1. --------------, Keputusan Menteri Negara Lingkungan Hidup Nomer 202 tahun 2004 tentang Baku Mutu Air Limbah Bagi Usaha dan atau Kegiatan Pertambangan Bijih dan atau Kegiatan Pertambangan Bijih Emas dan atau Tembaga.

2., Perda No 09/2012, Rencana Tata Ruang Wilayah Kabupaten

Halmahera Utara Tahun 2012-2032.

3., Malifut Dalam Angka,2016

4., Halmahera Utara Dalam Angka 2018

5., Maluku Utara Dalam Angka 2017

6., International Cyanide Management Code 2018

7. Chamid, Chusharini, dkk 2000, "Pengujian dan Penyempurnaan Rancangan Retort Merkuri Tepat Guna Untuk Pertambangan Emas Rakyat", Laporan Penelitian, LPPM UNISBA.

8. Chamid, Chusharini, dkk 2002, "Sosialisasi Retort Merkuri Tepat Guna Pada Unit Pertambangan Emas KUD Mekarjaya, Cineam, Tasikmalaya", Laporan Pengabdian Kepada Masyarakat, LPPM UNISBA.

9. D’Hondt, L, Konflik Pertambangan di Maluku Utara:Mencari Keadilan di antara keuntungan, identitas adat dan lingkungan, Chapter 10, 2011

10. Edward, Pengamatan kadar Merkuri di Perairan Teluk Kao (Halmahera) dan Perairan Anggai (teluk Obi) Maluku Utara, Makara, Sains, Volume 12 No 2, November 2008, Page 97-101.

11. Gustin, D et all, Politik Ruang dan Perlawanan:Kisah Konflik atas Ruang Di tingkat Lokal,'Dampak Kebijakan ruang Terhadap Perempuan di Lingkar Ruang Tambang NHM, Jaringan Kerja Pemetaan Partisipatif,2014

12. Simange, S.M, Penyebaran Merkuri dan Sianida Akibat Usaha Pertambangan Emas di Daerah Telok Kao, Kabupaten Halmahera Utara,Jurnal Agroforestri X Nomer 2 Juni 2015

13. Sulistijo, Budi. Totok D., Teti I., Meky A. Peningkatan Desa Tertinggal di Beberapa Desa Perbatasan Papua New Guinea Melalui Penyuluhan Pertambangan Plus. Pertemuan Perhapi, Jakarta 29 Agustus 1996

14. U.S. Environmental Protection Agency, 1995, "Integrated Risk Information System; case of Mercury Elemental",

15. USGS, 2000, "Mercury in the Environment".

16. Veiga. M.,Marcello, 1997, "Introducing New Technologies for Abatement of Global Mercury Pollution in Latin America", CETEM-Centro de Tecnologia Mineral, Cidade Universit'aria,I. do Fundao, Rio de Janeiro, Brazil. 
